\title{
Science and Race
}

\author{
Images, Objects, Maps
}

\author{
Mauro Capocci | ORCID: 0000-0002-3455-9019 \\ University of Pisa, Pisa, Italy \\ mauro.capocci@unipi.it
}

Claudio Pogliano

University of Pisa, Pisa, Italy

claudio.pogliano@unipi.it

"The Doubled History of Photography and Anthropology" is the title of the first chapter in a book published in 2011. Its author, Christopher Pinney, points out and retraces over the course of time "a curious echo" between the advent and the development of the two areas of activity. ${ }^{1}$ Quite early on, in fact, importance was given to the role that new photographic techniques could play in comparative anthropology. It was September 2, 1844 when the physician and embryologist Étienne Serres presented to the Académie des Sciences five daguerreotypes taken by E. Thiesson of two "Botocudes." The Botocudos were nomadic huntergatherers who belonged to a group of Brazilian tribes that had been progressively expelled from their original territory by Portuguese colonists, who did all they could to suppress them. Serres noted "the clarity of these prints, as well as the exactness with which the characteristics that distinguish this human type are reproduced." He added that a collection of similar pictures relating to different races would have been of the greatest interest to the natural history of mankind. ${ }^{2}$

1 Christopher Pinney, Photography and Anthropology (London: Reaktion Books, 2011), 17-62. The author is Professor of Anthropology and Visual Culture at University College London.

2 “... la netteté de ces épreuves, ainsi que l' exactitude avec laquelle sont reproduits les caractères qui distinguent cette varieté humaine." Comptes rendus hebdomadaires des séances de l'Académie des Sciences 19 (1844): 490. 
The following year, after François Arago had shown his colleagues at the Académie des Sciences some photographs of black persons taken in Lisbon, these too by Thiesson, Serres reiterated the need to reach the same level of knowledge in the study of human races that zoology had achieved. In the pursuit of their goal, only the creation of large museums had allowed zoologists to replace inaccurate verbal descriptions with the direct examination of objects. Since anthropologists still lacked this approach, "the speculative dimension of science got the upper hand over its positive dimension [la partie speculative de la science a pris le dessus sur sa partie positive]"; hypotheses and systems had to make up for non-existent facts. Since it was objectively quite difficult to gather authentic material, it was necessary to rely on the faithful representation of physical traits that only photography could provide. Indeed, Daguerre's brilliant invention offered the possibility of creating a museum of photographic images where modifications and transitions in racial types could be exhibited without having to embark on arduous scientific expeditions. Since Europe's cities and seaports often offered the opportunity to meet and observe natives from distant continents "in the flesh," it became simply a matter of fixing their physical aspect on the photographic plate.

Up to then, in Serres' view, philosophers and anthropologists had failed to serve science well. Philosophers believed that the transition from ape to man could be found in the so-called "Ethiopian race," thus unwittingly paving the way for the hideous slave trade; by comparing blacks with Europeans, the hiatus between the two ended up being exaggerated. Anthropologists realized that in order to assign Africans to their proper rank in the human family, it was essential to study the visual evidence and, with its speed and accurate recording of detail, photography provided the ideal tool. ${ }^{3}$ As Serres declared, he himself sought to abstain from any judgment until he had sufficient visual evidence.

In contrast, the outstanding naturalist Louis Agassiz was an outspoken partisan of racialism since his move from Neuchâtel to Boston in 1846. Making a tour for the purposes of introducing himself to the American scientific community, he spent some time in Philadelphia, where he was impressed by the collection of 6oo skulls that Samuel George Morton had assembled and illustrated in his renowned Crania Americana (1839). In a letter the usually somewhat stiff Swiss scientist confessed his "impression pénible" with regard to the black servants in the hotel where he was staying, a feeling that contradicted every idea of brotherhood of the human species: "They are not of the same blood as us."

3 Étienne Serres, "Observations sur l'application de la photographie à l'étude des races humaines," Comptes rendus hebdomadaires des séances de l'Académie des Sciences 21 (1845): $242-245$. 
Philanthropists who wanted to make nègres full citizens forgot their natural limits: they were humans — he would soon be arguing — but totally different from Whites. ${ }^{4}$

On March 15, 185 o Agassiz was attending a meeting of the American Association for the Advancement of Science held in Charleston, South Carolina and took advantage of the occasion to explain his viewpoint in greater detail. $\mathrm{He}$ said that all the races of man should be regarded as one species that was in possession of all the attributes of humanity, attributes that raised them above the brutes and allied them to the Deity. Nevertheless, zoologically the human races were very well marked and could be distinguished from one another; they did not at all come from a common center nor from a single pair. While opposing the dogma generally defended by Christian theology, he argued that his own opinion did not militate against the teachings of the Scriptures, because as early as the days of Cain there were other, already peopled lands in which the wandering murderer Cain could take refuge. Agassiz addressed the question more fully in an article that denied — albeit in a somewhat ambiguous waythat there was a link between polygenism and the defense of slavery: "Is that a fair objection to a philosophical investigation? Here we have to do only with the question of the origins of men; let the politicians, let those who feel themselves called upon to regulate human society, see what they can do with the results." Basically, Agassiz asserted that the unity of species—-which he claimed to support-did not involve a unity of origin. ${ }^{5}$

This long premise leads us to a significant project undertaken by Agassiz. Following the Charleston meeting, he made a tour of the plantations around the city of Columbia, selected some slaves of African descent, and commissioned a local photographer, Joseph T. Zealy, to produce a series of daguerreotypes of these 5 men and 2 women. Agassiz's aim was to identify and illustrate the different types making up the black population of South Carolina based on their physical traits as recorded in photographs taken from different angles: front, back, and side profiles. In these photographs nude torsos or standing figures were presented for public scrutiny. In 1850 this form of visual documentation

4 "Il ne sont pas du même sang que nous." See Agassiz's long letter to his mother and friends, December 2, 1846, Ms. Am 1419, Houghton Library, Harvard University: https://iiif.lib.harvard .edu/manifests/view/drs:12379926\$326i

5 Agassiz's remarks were published in Proceedings of the American Association for the Advancement of Science. Third Meeting, held at Charleston, S.C., March 1850 (Charleston, S.C.: Walker and James, 1850): 106-107; Louis Agassiz, "The Diversity of Origin of the Human Races," Christian Examiner 49 (1850): 113. Regarding his position during the 186os on the questions of abolition and segregation, see Christoph Irmscher, Louis Agassiz: Creator of American Science (Boston-New York: Houghton Mifflin Harcourt, 2013), 219-269. 
was still in its infancy, but output would quickly multiply. In an insidious power play, images were produced that created the perception of an inescapable physical "separateness" when they were compared with conventional portraits of white slave owners whose elegant demeanor and dress bespoke their position of wealth and domination. For Agassiz, the material form was the "cover of the spirit," and this separateness also affected the moral sphere. ${ }^{6}$

In January 1876 Nature published a short review of an extraordinary album that won a medal at the International Exhibition of Vienna in 1873. Carl Dammann, a portrait photographer based in Hamburg, had been commissioned by the Berliner Gesellschaft für Anthropologie, Ethnologie und Urgeschichte to collect images from various sources of individuals belonging to different ethnic groups in order to create a pictorial compendium of ethnological knowledge for general dissemination. The large-format, 5o-page album featured 642 photographs in a variety of layouts, each of them accompanied by a caption. The author of the review was none other than the eminent cultural anthropologist Edward B. Tylor, who stated in no uncertain terms that "the science of anthropology owes not a little to the art of photography." It is true that in the past a handful of artists had taken a special interest in the portrayal of subjects belonging to non-Caucasian, "exotic" races, among them the American George Catlin (1796-1872), well known for his paintings of New World natives, and the British artist William John Burchell (1781-1863), who traveled through South Africa at the beginning of the century and produced portraits of Hottentots and Bushmen. However, up to the late 19th century most of the engravings to be found in books were worthless from a scientific perspective, "... either wanting the special characters of the race, or absurdly caricaturing them." At that time only photographic portraits could lay some claim to ethnographic value; as Tylor maintained, Dammann's album was one of the most important contributions to the science of man and he wished it all success. ${ }^{7}$ Indeed, not

6 It was only in 1976 that Zealy's fifteen daguerreotypes were rediscovered in storage at the Peabody Museum of Harvard University. They were exhibited for the first time in 1986 and published in the catalogue of the exhibition; see Melissa Banta and Curtis M. Hinsley, eds., From Site to Sight: Anthropology, Photography, and the Power of Imagery (Cambridge, Mass.: Peabody Museum Press, 1986). The daguerreotypes underwent restoration between 2007 and 20o9. See also Brian Wallis, "Black Bodies, White Science: Louis Agassiz'a Slave Daguerreotypes," American Art 9 (1995): 38-61, and Molly Rogers, Delia's Tears: Race, Science, and Photography in Nineteenth-Century America (New Haven-London: Yale University Press, 2010). For a more recent collection of essays examining the image of the slave, the creation of this image, the people behind the camera and the people in the frame, see Ilisa Barbash, Molly Rogers, and Deborah Willis, eds., To Make Their Own Way in the World: The Enduring Legacy of the Zealy Daguerreotypes (New York: Aperture and Peabody Museum, 2020).

7 Edward B. Tylor, "Ethnological Photographic Gallery of the Various Races of Man," Nature 13 
infrequently the observation can be found in the ethnographic literature of the time that "it is better not to rely on written descriptions only, but to secure if possible photographs of natives." ${ }^{\text {D }}$ Did this perhaps reflect a distrust of verbal communication?

\section{The Objects of Anthropology}

Over the course of just a few decades, between Serres, Agassiz and Tylor, an unmistakable rhetoric of disinterested empiricism fueled the cult of objects (and objectivity), objects either displayed in museums or visually represented by means of a chemical-optical procedure. In the eyes of both those who produced them and those who viewed them, objects and photographs seemed to speak for themselves, as if they paved a royal road to knowledge, with the effect moreover of somewhat discrediting the art of illustration, which had been the only means of representation up to that time. ${ }^{9}$

Could it be only a coincidence that as soon as he was appointed to his university chair, Paolo Mantegazza, founder of the Italian school of anthropology, established-in Florence in 1870 (although others would soon follow) - the first anthropological museum in Europe? And not by chance he was an ardent promoter of photography as an essential tool of the discipline of anthropology, conceived as a very broad science of man. For the remainder of his career Mantegazza would use photography to document his research. Mankind was to be studied "come si vede e come si tocca [as one can see and touch it],"

(1876): 184-185. See Carl F.W. Dammann, Anthropologisch-ethnologisches Album in Photographien (Berlin: Wiegandt, Hempel \& Parey 1873/74), and the English edition (London: Trübner and Co., 1876). The same progress in terms of putative 'objectivity' which supposedly took place during the transition from painting to photography was reported by another reviewer of Dammann's work, Gustav Fritsch, who suggested that a less expensive edition would contribute to the dissemination of this important work; see Zeitschrift für Ethnologie 6 (1874): $67-69$.

8 William Y. Turner, "The Ethnology of the Motu," The Journal of the Anthropological Institute of Great Britain and Ireland 7 (1878): 473. Reverend Turner had resided for 6 months in and around Port Moresby on the Papuan Peninsula, where the London Missionary Society established numerous outposts. Engravings copied from photographs are included in his report, "so arranged as to place that of a Motu between a Papuan and a Malayo-Polynesian, so that a glance will decide to which of the two great families into which the inhabitants of Polynesia are divided the Motu belongs." (Ibid.)

9 See Anne Lafont, "Du dessin au musée: comment faire des êtres humains des objets?," https:// www.politika.io/fr/notice/du-dessin-au-musee-comment-faire-etres-humains-objets, accessed September 7, 2021. 
in all of its aspects, physical as well as intellectual and moral, applying the same observational criteria that had long been adopted for stones, plants, and animals. Just describe what you find, do not suppose or invent anything, and build your theories on the basis of collected facts only. Thus his epistemology, entirely in line with the times, prescribed how the anthropologist should act. ${ }^{10}$ Mantegazza's expeditions to Lapland and India, along with their visual documentation, are well known. In 1889, when the Società fotografica italiana was created in Florence, he served as its first president and delivered a speech extolling the technique that was then celebrating its first half-century of life. ${ }^{11}$

Many other examples of the documentation of anthropological data during the second half of the 19th century may be found, but what matters here is the complicity that developed between scientific activity, the material/visual approach, and race as a construct. This special issue of Nuncius offers a sample of cases aimed at illustrating, in different ways, a sort of circularity that rapidly took shape. Since the mid-19th century, a series of historical events and epistemic changes have been reconfiguring the force field from time to time, so that systematic research could also chart the shifting curve of relationships among the elements at stake. Undoubtedly, for instance, changing attitudes toward human diversity induced notable transformations in collecting practices and in the setting up of museums as archives of material objects, major vectors in the conveying of an interpretation of history to the general public. The contextualization of history in colonial and post-colonial settings is far from linear, and of course geographically quite varied. ${ }^{12}$

10 Mantegazza's inaugural lecture in Florence—given on January 14, 1870—was published with the title "Del metodo dei nostri studi antropologici," as an introduction to his Quadri della natura umana. Feste ed ebbrezze (Milano: Brigola, 1871), I:7-34.

11 Paolo Chiozzi, "Fotografia e antropologia nell'opera di Paolo Mantegazza (1831-1910)," AFT. Rivista di Storia e Fotografia 6 (1987): 56-61; Brunetto Chiarelli, Paolo Chiozzi, and Cosimo Chiarelli, La Scuola antropologica fiorentina e la fotografia tra '8oo e '9oo (Firenze: Museo di Storia della Fotografia, 1996); Monica Zavattaro et al., eds., Obiettivo Uomo. L'antropologia fotografica di Paolo Mantegazza (Signa, Firenze: Masso delle Fate, 2010); Cosimo Chiarelli, "Mantegazza e la fotografia: una antologia di immagini," in Paolo Mantegazza e l'evoluzionismo in Italia, ed. Walter Pasini and Cosimo Chiarelli (Firenze: Firenze University Press, 2010), 95-99, https://oa.torrossa.com/it/resources/an/2442843.

12 At least brief mention should be made of the pioneering work of George W. Stocking, Jr., who in the 1980 edited a well-known series "History of Anthropology," the third volume of which contains essays by various authors on Objects and Others, Essays on Museums and Material Culture (Madison: The University of Wisconsin Press, 1985). See also Tony Bennett, Pasts Beyond Memory: Evolution, Museums, Colonialism (London and New York: Routledge, 2004); Mary Bouquet, Museums: A Visual Anthropology (London-New York: Berg, 2012); Alice L. Conklin, In the Museum of Man: Race, Anthropology, and Empire in 
Lastly, it is worth mentioning that in 1984 the Royal Anthropological Institute (UK) was awarded a grant by the Calouste Gulbenkian Foundation for a pioneering project-European Encounters with the Third World - to research its rich collection of visual materials. A collaborative effort lasting some years led to the publication of a seminal work edited by Elizabeth Edwards, who afterwards would continue to pursue this line of research. With Christopher Morton she has more recently assembled another set of contributions that they introduce with the following neat statement: "Anthropology, whatever its intellectual twists and turns over the years, remains a highly visualized practice. This has resulted in a rich photographic legacy, both intentional and incidental."13 And indeed visual anthropology is a subfield that has grown and matured over time, with the emergence of university courses, conferences, societies, and specialist interest groups. ${ }^{14}$

Needless to say, it would have been extremely complex, if not impossible, and probably inappropriate to deal with the general topic of science and race in the limited space of a special issue such as this. A boundless corpus of historiography already exists, which has expanded greatly in recent decades: simply reviewing it would impose an arduous selection and carry serious risks. For this reason, we chose to narrow the topic down and address it according to the orientation that distinguishes Nuncius, as its subtitle-Journal of the Material and Visual History of Science - announces, which left our contributors free to develop their own particular themes. The outcome is a polyphony of voices covering a broad range of interests.

\section{3} A Reader's Guide

The essays contained herein can be browsed along different lines. The reader may wish to explore geographic areas: Europe, Asia, the Americas. Or he/she may prefer to study physical instruments: photographs, exhibitions, filmed material, museum collections. The topics addressed in the essays can be

France 1850-1950 (Ithaca and London: Cornell University Press, 2013).

13 Elizabeth Edwards, ed., Anthropology and Photography 1860-1920 (New Haven and London: Yale University Press, 1992); Christopher Morton and Elizabeth Edwards, eds., Photography, Anthropology and History. Expanding the Frame (London and New York: Routledge $\left.2016^{2}\right)$, see the editor's introduction.

14 Marcus Banks and Jay Ruby, eds., Made to Be Seen. Perspectives on the History of Visual Anthropology (Chicago and London: The University of Chicago Press, 2011). When searching "Visual Anthropology" (September 2020), Academia.edu pulled up almost 200,00o full text citations. 
grouped chronologically or divided according to historiographical style. In fact, the collection represents a "global" material history of anthropology, spanning the connections between colonial powers and their colonies, encounters among different cultures, a variety of approaches and research methodologies, international meeting spaces, the circulation of knowledge and objects, the creation of national and international borders, and the making of nations. All of these themes can be found interwoven in this collection.

As far as geography is concerned, the papers cover the entire planet. Da Silva and Arteaga analyze the British anthropological gaze on the indigenous peoples of the Amazon, as realized in the ethnographical section of the Natural History Department in the Crystal Palace, which was reconstructed in the mid185os. Materiality is expressed in this paper by images published in the press, photographs of the original exhibition, and drawings in the visitor's guide to the Natural History Department. Science and race are deeply embedded in the creation of the notion of the "savage" peoples, following the ethnology of Robert Latham and Alfred Russell Wallace. This paper also highlights the relationship between science and its Victorian public: the material analyzed here was directed to a lay audience to whom natural history, and science in general, were a source of wonder and education. ${ }^{15}$ Scientists used this new arena to parade their theories, gaining visibility for concepts and human beings alike. In their paper, Da Silva and Arteaga show how Wallace exploited his involvement in the Crystal Palace exhibition to increase his own credibility in scientific circles, aided by the fact that the curator of the section was Robert Latham, probably the most prominent British ethnologist of the time. They shared a bio-geographical perspective on anthropology-a vision that Wallace was to fully develop later in his expedition to South East Asia, as is clearly reflected in the visual arrangement of the Crystal Palace exhibition. Furthermore, Wallace's contribution was instrumental in adding one more piece to Britain's imperial mosaic: the Amazonian "savages" were from the newly conquered colonies in South America, and as such they became a worthy subject of investigation for British anthropology.

The "visibilization" of a colonized people lies at the core of Kortegangas' paper. In the 1920s, while working as a geodesist and cartographer for the Finnish government in the Petsamo region (since 1947 a part of the Soviet Union), Karl Nickul came into contact with the Suenjel Sámi population. Fol-

15 Aileen Fyfe and Bernard Lightman, eds., Science in the Marketplace: Nineteenth-Century Sites and Experiences (Chicago: University of Chicago Press, 2007). See also the special issue (1/2012) of the journal Early Popular Visual Culture devoted to "Victorian science and visual culture," edited by Bernard Lightman. 
lowing that encounter he devoted himself to making the Suenjel Sámi visible by studying their lifestyle and culture, and popularizing their existence as a more "natural" and "original" Sámi population untamed by contact with other civilizations. The visual material presented in the paper, first published in a widely circulated monograph about the Suenjel Sámi, was instrumental to putting this ethnic group on the map, literally. What sparked Nickul's interest was in fact the different perspective adopted by the Suenjel Sámi in looking at the territory they inhabited. They named places in a completely different way with respect to "scientific" cartography, and according to Nickul their naming system was a testament to their closer relationship with nature. Eventually his "discovery" resulted in Nickul's request for self-governance for the Sámi in Finland, Sweden and Norway, connecting the population with other native peoples facing a similar form of colonization within national borders. The map drawn up by Nickul, which is presented in Kortegangas' paper, is in fact a signifier for Suenjel Sámi culture, illustrating the key role that can be played by visual and material objects in historical research; indeed, their ability to convey more profound and important meanings lies at the core of this special issue.

Other maps in this collection bear a similar significance, such as the ethnographical maps of the Philippines in Dayana Ariffin's paper, which compares two different attempts at racial grouping in the geography of the Philippines which resulted in two maps produced at the end of the 19th century under two different colonial governments. The racial cartography clearly shows how science responded to colonial power. The first map, which was produced for the Spanish administration, had different layers: race and religion were combined in a representation of the partial domination of the archipelago. The territories were divided according to ethnography, but also showed the limited extent of Spanish rule, which correlated closely with the spread of Christianity. When the Americans took control, the Spanish map was to a large extent conserved, although the advancement of racial science left its mark. The descriptions of the different ethnic groups were now much more detailed than before, though the main partition still reflected the earlier, religious bias. The science of race was called into action by creating a hierarchy among the different groups, becoming the basis for racial policies under the American administration. From this perspective, the evolution of the Philippine maps mirrors the increasing influence and involvement of anthropology in the exercise of colonial power: in this case, anthropological classification appeared to be instrumental in the "rational" planning of the domination by the colonial government of the natives. As such, the Spanish and American maps reveal more of the role of anthropology in society than of its theories and concepts, shedding light on the origins and establishment of the discipline. 
Another paper offers insight into the anthropology of this same region in the late 19th century. Ricardo Roque analyzes a specimen purportedly collected in Timor: a skull classified by Ernest Theodore Hamy as that of a negrito, which belonged to the anthropological collection of the Musée d'Histoire Naturelle in Paris. By means of a china ink inscription, the skull became a key piece in a larger picture that was used by Hamy to support the theory of his mentor, Armand de Quatrefages. The "Negrito de Timor" was the missing piece needed to demonstrate their thesis that this race was one of the two original Oceanic populations (the other being the Papuans). French anthropologists opposed Wallace's view of the Malays and the Papuans as the primeval races in the area. In their opinion, the wide distribution of the negritos, who originated in the Philippines but by then had reached as far as Timor, told a different story: they represented the most primitive race in the region, but their geographical distribution shrank over time as they were forced into ever more remote areas by the invasion of superior and more highly evolved ethnic groups. Leaving theory aside, the paper highlights the practices of anthropology. The materiality of the inscription played the role of a crucial experiment whose credibility rested on several factors, among them the reputation of the scientist, the authority of his institution, the scientific validity of the collection, and the theoretical context in which the specimen was framed. The international scientific community placed weight on all these elements, viewing them as integral to the epistemology of the discipline.

Practices and reputation are important issues in Iannuzzi's paper, which focuses on Lidio Cipriani's use of photography in his numerous expeditions across Africa. A staunch and outspoken supporter of the Fascist regime and its racist policies, Cipriani brought back to Florence a large collection of anthropological and ethnological photographs. These were later used in several of his publications-works written for the general public that fomented the traditional racist biases against African populations. His vast collection of photographs was bound in large volumes, each one presenting a visual narrative of the different ethnic group. The unusual format of the albums raises the question as to how Cipriani envisaged the use of these visual documents. A careful analysis of archival sources and his published works leads Iannuzzi to highlight the fact that the photographs included by Cipriani in his books were drawn from his albums but were disconnected from the textual narrative. From this perspective, the context gave meaning to the images in a deeply unscientific practice that was alien to the established tradition in anthropology. When Cipriani lost political support within the Fascist regime, he was unable to rebuild his reputation within the academy and his relative isolation led some historiographers afterwards to regard the albums sympathetically as a collec- 
tion of souvenirs from the past, created with nostalgia by an old man. However, the materials now tell quite a different story.

The narrative created with objects are also the main core of Falcucci's paper. However, whereas Iannuzzi focused on books and images, Falcucci examines museum spaces and how they were conceived and set up. The comparison between Italy, Belgium and France allows the reader to taste different flavors of colonialism. It is interesting how science benefitted from the "age of museums," which was ushered in during the 185 os in parallel with the "scramble for Africa." Museums and exhibitions displayed global power supported by a positivist approach to science. Science received support in return in the form of prestige and visibility. The exhibitions of colonial power were arranged accordingly, with ethnography and the natural sciences playing their parts in celebrating empire and the economic opportunities they offered. The use of science in the display of inferior races-either as enemies or as commodities-was one of the major aspects of the organization of colonial museums. Spaces and objects embodied a deeper meaning, creating an objectivizing environment for the human species and its products. African and other indigenous peoples were exhibited-live! — alongside the natural resources available in their native: White European progress was there to exploit both, in what was regarded as a historical and scientific necessity.

Progress - dressed as new technology - is focused on in the essays by SeraShriar and Pogliano. The first paper deals with one of the most dominant figures in the history of racial science, Francis Galton, who doggedly searched for the most effective instruments to turn human individuals into numbers and patterns. Sera-Shriar details how Galton's efforts to identify and define ideal racial types led him to develop a peculiar photographic technique, namely the superimposition of pictures in order to reveal similarities among series of individuals. If the photographs were collected from a sufficiently large and ethnically homogeneous group, he retained that the composite photograph demonstrated the traits shared by different individuals, resulting in an "ideal type" representative of the group under study. The Jewish population in England was an obvious subject for study using this means, especially when a fresh wave of Jewish migrants arrived from Russia in the 189os. The difference between the cultivated and wealthy British Jews and the newcomers was striking and called for an "objective" assessment. Technology seemed to provide the perfect tool for identifying the "Jewish type." Galton and the Jewish anthropologist Joseph Jacobs both applied this technique, but their conclusions diverged. Where Galton saw biological heredity at work, Jacobs pointed to the cultural history of the Jewish population in different countries: the "Jewish expression" was the result of a history of oppression and discrimination. In fact, the new "objective" tech- 
nology endorsed by Galton was anything but neutral, and the same applied to the scientists using it. The photographs in Sera-Shriar's paper speak eloquently, testifying to one of the fundamental meanings of a visual approach to history: the reconstruction of the epistemological processes underlying theories, processes that can eventually shape reality itself. Do visual technologies-e.g., photography-enhance or hinder this process?

This question looms large in the essay by Pogliano, which is devoted to the early development of ethnographic cinema. The possibilities offered by this medium were quickly grasped and it was soon being applied, on the one hand to film human activities of ethnographic interest such as a particular dance or ceremony, and on the other hand to allow scientists to study physical phenomena (such as the simple act of walking) in revelatory detail. The trajectory of cinematography (in both senses) as applied in ethnology mirrored the development of the latter. After the initial wave of enthusiasm for the filming of native customs and practices, the progressive detachment of ethnology from social evolutionism would gradually reduce the use of cinematography, as interest shifted from the study of visual phenomena that could be recorded in the form of photographs and film to linguistic analysis and other "invisible" cultural structures and practices.

This draws our attention once again to the connection between the epistemology of the racial sciences and the available technologies. While there was no direct technological determinism in this relationship, there was a complex entanglement of concepts and actions, often carefully chosen within the boundaries drawn by the relevant scientific community. Science was treading on treacherous ground here, as both technological innovations and social factors (such as political changes bringing new Jewish immigrants to UK) require some sort of theoretical justification before being accepted, the first as valid instruments and the second as valid conditions for the conduct of scientific research. Any visual or material object created in this practice is a point in a changing configuration of power within the community: the power of theories and the power of individuals. By observing these configurations over time and space, we are able to expand the perspective of "epistemic things" and "epistemic objects,"16 underlining the peculiarity of the anthropological disciplines. In this domain, objects-especially when dealing with racial science-have

16 Hans-Jörg Rheinberger, Toward a History of Epistemic Things (Stanford: Stanford University Press, 1997); Karin Knorr Cetina, "Objectual practice," in The Practice Turn in Contemporary Theory, ed. Karin Knorr Cetina, Theodore R. Schatzki, and Eike von Savigny (London: Routledge, 2001), 175-188. 
intrinsic human meaning. In fact, objects constitute the meeting point of several actors, connecting faraway worlds and layers of meaning.

How did Western science cope with the most intimate connection between these faraway worlds - reproduction? By using visual patterns! In the opening essay Staffan Müller-Wille argues that symbolic representations of geography and races since the 17th century show great consistency in their evolution. Separation and diversity were gradually replaced by arithmetic calculation involving blood proportions, and the visual depiction of races was both one of the causes and one of the effects of sciences that were trying to make sense of human diversity. The predominant diagrams of the period visually informed the concepts regarding race, so that it is possible to imagine a visual history of concepts and at the same time a conceptual history of visual representations. Does "diagrammatic" reasoning on race and ethnicity still apply to contemporary life sciences? The question is all the more important today, as "big data" science shapes human genomics and anthropology, and direct-to-consumer DNA tests have replaced blood proportions in defining ethnicity. ${ }^{17}$

With this introduction we hope to have shown a possible route to navigate through the collection of essays; however, as noted at the beginning, there is no single route. It is for this reason that, after much thought we decided to arrange the contents of this special issue under three different headings, each one devoted to a specific material category: images, objects, and maps. Obviously, maps are both objects and images, objects project images and can be arranged in maps (as in a museum), and images can represent objects. Encyclopaedism was beyond the scope of this issue, but nevertheless we as editors had a shot at multiplicity. In this multiplicity, each reader will be able to create a unique pattern of exploration based on his or her research interests, hopefully enjoying every step in the journey.

17 See for example Catherine Bliss, Race Decoded: The Genomic Fight for Social Justice (Stanford: Stanford University Press, 2012); Kimberly TallBear, Native American DNA. Tribal Belonging and the False Promise of Genetic Science (Minneapolis: University of Minnesota Press, 2013); Ruha Benjamin, Race After Technology. Abolitionist Tools for the New Jim Code (Medford, MA: Polity, 2019). 